Mycologia, 96(5), 2004, pp. 1141-1149.

(C) 2004 by The Mycological Society of America, Lawrence, KS 66044-8897

\title{
The southernmost myco-heterotrophic plant, Arachnitis uniflora: root morphology and anatomy
}

\author{
Laura S. Domínguez ${ }^{1}$ \\ Alicia Sérsic \\ Instituto Multidisciplinario de Biología Vegetal \\ (IMBIV), C.C. 495, 5000 Córdoba, Argentina
}

\begin{abstract}
Root morphology and anatomy of the myco-heterotrophic Arachnitis uniflora (Corsiaceae) were studied in relation to their association with a Glomus species (Glomeromycota). The mycorrhizal features were studied in three distinctive stages of development: (i) shoot and flower restricted to a small, underground bud; (ii) shoot and flower bud up to $1.5 \mathrm{~cm}$; and (iii) shoot and flower already withered. The hyphae penetrate through and between the epidermal and exodermal cells; the exodermis and outer cortical cells become colonized in an inter- and intracellular manner, with some coils being formed in these layers. The fungi colonize the middle cortex, where intracellular vesicles in bundles are abundant. Arbuscules are formed profusely at very early stages of development, while in older stages they almost disappear and abundant vesicles are formed. Except for some details, the pattern of root colonization corresponds to a Paris-type. Presence of storage substances (starch and oil) also was recorded. Starch is produced and stored within root cells, mainly in the outer and inner root cortex. In senescent stages, plant and fungal tissues collapse.
\end{abstract}

Key words: achlorophyllous plant, arbuscular mycorrhiza, Corsiaceae

\section{INTRODUCTION}

Achlorophyllous vascular plants, which are unable to assimilate carbon by themselves and consequently depend on their association with fungi for nourishment commonly were called "saprophytic" plants. This misleading term, which implies that plants obtain carbohydrates directly from decaying organic matter, nowadays is being replaced by the more precise term "myco-heterotrophic" (Leake 1994). Myco-heterotrophy has evolved many times and has been recorded in 10 families: six within the Monocots (Burman-

Accepted for publication April 6, 2004.

${ }^{1}$ Corresponding author. E-mail: laura@imbiv.unc.edu.ar niaceae p.p.-incl. Thismiaceae, Corsiaceae, Iridaceae p.p., Orchidaceae p.p., Petrosaviaceae, Triuridaceae -incl. Lacandoniaceae) and four in the Dicots (Gentianaceae p.p. Monotropaceae, Polygalaceae p.p. and Pyrolaceae p.p.), comprising about 88 genera and 400 species (Maas et al 1986, Rübsamen 1986, Mabberly 1987, Dressler 1993, Leake 1994, Ibisch et al 1996). Four major types of mycorrhizal associations have been described for myco-heterotrophs (after Leake 1994): arbutoid, monotropoid, orchid, and arbuscular (AM), whereas the arbutoid mycorrhiza $P y$ rola may be without myco-heterotrophic species (Furnam and Trappe 1971). AM are formed by fungi belonging to Phylum Glomeromycota (Schüssler et al 2001). Arbuscular mycorrhizal infection has been shown or suggested to occur in species of the Burmanniaceae, Corsiaceae, Gentianaceae, Polygalaceae, Pyrolaceae and Triuridaceae (van der Pijl 1934, McLennan 1958, Terashita and Kawakami 1991, Leake 1994, Imhof 1997, Imhof and Weber 1997, Domínguez, et al 1998, Imhof 1998a, 1999a, b, c, Domínguez and Sérsic 2001). Sequence analysis of the ITS region recently has confirmed the association of Gentianaceae, Corsiaceae (Bidartondo et al 2002) and Triuridaceae (Yamato 2001) with a lineage of AM fungi (Glomus).

Corsiaceae is a small family with three genera (Corsia Becc., Corsiopsis D.X. Zahng, R.M.K. Saunders \& C.M. Hu and Arachnitis Phil.) and 29 species all restricted to the Southern Hemisphere. The 26 Corsia species are native to Australasia, while the monotypic genus Corsiopsis inhabits China (Rübsamen 1986, Zhang \& Saunders 1999). Arachnitis grows in Bolivia, in the Patagonian Nothofagus forests of Argentina and Chile and in the Falkland Islands (Dimitri 1972, Cribb et al 1995, Ibisch et al 1996). This genus is monotypic, with only A. uniflora Phil. It has been suggested recently that Corsiaceae is probably polyphyletic and Arachnitis appears to be related to Thismia (Thismiaceae) in a larger clade that also includes Burmanniaceae (Neyland and Henningan 2003).

The mycorrhizal associations of these achlorophyllous plants are poorly known with respect to their morphology, physiology and fungal symbiont. Taxonomical and biological studies of myco-heterotrophic plants are difficult because they spend most of their lives underground, becoming visible only during the 

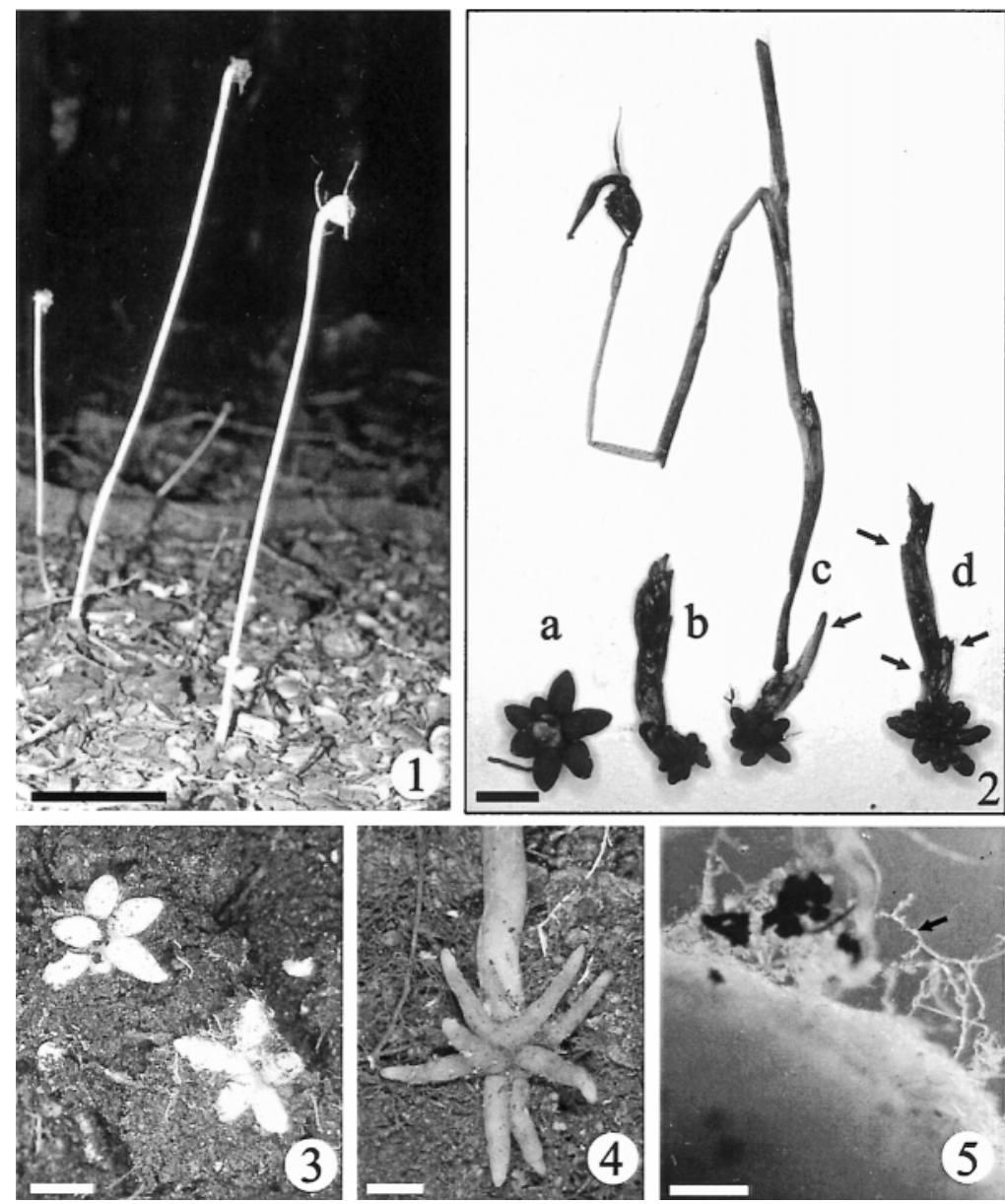

Figs. 1, 3-5. Plants and roots of Arachnitis uniflora. 1. Flowering plants in natural habitat. 2. Different stages of plant development: a. young specimen with turgent root system, shoot and flower restricted to a small bud, b. shoot and flower bud beginning to develop, basal part of the shoot with bracts (arrows), c. fully developed plant at fruit stage, d. senescent plant with dead shoot. 3. Turgent roots of young specimen. 4. Long and tapering root system of a withered plant. 5. Root surface with external hyphae (arrow). Scale bars: $1=5 \mathrm{~cm} ; 2-4=0.5 \mathrm{~cm} ; 5=200 \mu \mathrm{m}$.

flowering and fruiting season. Some are mimetic with the environment; thus collections of these plants are rare.

In this work, presence and morphology of the mycorrhizal structures in three different stages of plant life cycle of A. uniflora are studied.

\section{MATERIALS AND METHODS}

Plants of A. uniflora were collected from dense and shaded forests, in loose organic soils, with abundant leaf and wood litter (FIG. 1). They co-exist with Austrocedrus chilensis (D.Don) Pic. Serm \& Bizzarri and Nothofagus dombeyi (Mirb.) Oerst. trees and Osmorrhiza chilensis Hook \& Arn., Berberis sp., Escallonia sp. as some species of the understory. Individual plants were excavated and several whole root systems were detached for examination $(n=45)$, while underground buds close to them also were preserved. Aboveground parts of the plants were dried as herbarium specimens and the root systems preserved in formalin (40\%): acetic acid (100\%) : ethanol $(96 \%)$ : water at 10:5:50:35, as well as in glutaraldehyde $(50 \%)$ and buffer $\mathrm{pH} 6.8$ at 24 : 100 , before being transferred to ethanol $(70 \%)$ after $24 \mathrm{~h}$ (O'Brien and McCully 1981).

Specimens examined. ARGENTINA. CHUBUT: Departamento Lake Cholila, 41 ${ }^{\circ} 54^{\prime} 42.1^{\prime \prime} \mathrm{S}, 72^{\circ} 24^{\prime} 24.6^{\prime \prime} \mathrm{W}, 7 \mathrm{Jan} 1994$, $A A C$ 525, (CORD). Additional specimens were fixed at the same locality on 18 Jan 1998. NEUQUÉN: Departamento Los Lagos, Villa La Angostura, Laguna Verde, 40 46 $37.9^{\prime \prime} \mathrm{S}$, $71^{\circ} 39^{\prime} 31.6^{\prime \prime} \mathrm{W}$, elevation $813 \mathrm{~m}, 14-15$ Dic 2001, AAC 1406, (CORD). RÍO NEGRO: Departamento Bariloche. Road to Llao Llao, Km. 6.5, 41 ${ }^{\circ} 7^{\prime} 16.2^{\prime \prime} \mathrm{S}, 71^{\circ} 23^{\prime} 31.2^{\prime \prime} \mathrm{W}$. 14-15 Dec 2001, AAC 1406, (CORD).

In the laboratory, the roots were examined under a stereomicroscope. Roots of five plants at different stages of development were embedded in synthetic resins following the manufacturer's instructions (Kulzer Histo-Technique 7100 ), then cut into $4 \mu \mathrm{m}$ thick sections (approximately 400 sections per root) and stained with Cresyl blue (Largent et al 1977). Different stains also were tested for the fungal symbiont (cotton blue and trypan blue) (Largent et al 
1977). Lugol iodine solution was used to detect starch, and Sudan IV was used to detect oil content (Gerlach 1984).

Macroscopic photographs were taken with a Leica M 420 photostereomicroscope. Sections were observed and photographed with a Leitz DM LB photomicroscope.

\section{RESULTS}

Plant morphology.-Roots of A. uniflora grow between the mineral and organic soil horizons at depths of ca 10-15 cm. The root system consists of a star-like conglomeration of (6)10(17) $(\mathrm{n}=5)$ tuberous roots (FIGS. 2-4); each root is about $5-10 \mathrm{~mm}$ long $\times 3-4 \mathrm{~mm}$ wide. No side roots or hairs were observed. Root sprouts are found rarely. Fully developed roots are bluntly tapering (FIG. 3). Root formation precedes shoot development. Once a clump of roots has developed completely, a shoot bud is formed (FIG. 2a). The stem may grow from $6 \mathrm{~cm}$ up to $40 \mathrm{~cm}$, depending on plant populations, and produces a single zygomorphic flower (FIG. 1, 2c). The shoot base is covered by 4-5 translucent bracts (FIG. 2d). Stem and flower are variable in color, being whitish, yellowish or purple. No odor was detected. The fruit is a capsule with a terminal opening, filled with numerous small seeds $(0.7 \times 0.06 \mathrm{~mm})$.

Root anatomy.-Abundant debris and rhizospheric organisms, such as bacteria and hyphae, surround the root surface and fill epidermal depressions or crypts (FIGS. 5, 7). Cross sections of mature roots show one layer of an uneven epidermis, followed by 2-3 cell-layered exodermis (FIGS. 6, 8). The outer tangential cell wall of the epidermis is up to $2 \mu \mathrm{m}$ thick, with the other walls measuring only $0.6 \mu \mathrm{m}$. Based on morphology, there appears to be an exodermis, which is composed of tangentially elongated cells $(15-26 \times 30-45 \mu \mathrm{m})$ (FIG. 8). Middle lamellae are easily distinguishable between the cells of the exodermis but less evident in the outer cortical layers. The cortex, comprising the largest volume of the root, consists of three distinct regions of parenchyma cells. Two to three layers of tangentially elongated cells $(8-12 \times 20-30 \mu \mathrm{m})$ form the outer cortical region, next to the exodermis (FIGS. 6, 8), while the middle and inner regions are multilayered with more isodiametric cells $(25-150 \mu \mathrm{m}$ and $10-30 \mu \mathrm{m}$ respectively) (FIGs. 17-18). Intercellular spaces are evident only in the inner parenchymatic layer (FIG. 21). When the shoot and flower begin to develop, the epidermis, exodermis and outer cortex cells become more isodiametric (FIG. 17). The central cylinder (FIG. 17) is built of scattered groups of phloem cells and some xylem elements. These xylem elements can be distinguished clearly only in older roots. Although a typical endodermis could not be discerned, there is an uneven row of more or less spherical cells (17$50 \mu \mathrm{m}$ diam). Lugol's stained transversal sections showed that epidermal and exodermal cells do not contain starch. The outer- and innermost cortical regions are characterized by an accumulation of high amounts of composite starch grains (FIGS. 22-23). In the mid cortical parenchyma cells, where a profuse fungal colonization takes place, starch grains are sparse. Oil globules were found inside and outside the fungal hyphae, especially in the early stages of root development (FIG. 24).

The endophyte. Infection and development.-The externally attached mycelium (FIG. 5) is characterized by aseptate (a septum was seen only once), irregularly shaped, up to $1 \mu \mathrm{m}$ thick-walled and ramified hyphae (5-12 $\mu \mathrm{m}$ diam). No root-to-root attachments with neighboring plants were seen. The root surface does not show any particular coloration around the points of hyphal penetration.

Three distinctive stages of development were studied: (i) shoot and flower restricted to a small underground bud (FIG. 2a); (ii) shoot and flower bud beginning to develop (FIG. 2b); and (iii) shoot and flower already withered (FIGS. 2c,d).

Before the shoot bud emerges, a star-shaped root system consisting of short and turgent roots develops (FIG. 3) (stage i). Sections of the entire root system including the apical shoot bud show that neither the shoot tissue nor the meristematic cells of the root apex or the central cylinder become colonized. However, fungal colonization is widespread in other root tissues. The hyphae gain entrance by forcing their way between the epidermal cells and go into the outer exodermal layer (FIG. 8). No appressoria were seen. Once inside, the intruding thin $(0.8 \mu \mathrm{m})$ walled hyphae, grow toward the middle cortex layers in an inter- and intracellular manner (FIGS. 9-10). The hyphae (up to $8 \mu \mathrm{m}$ diam), during cell-wall passage, spread, ramify and pass without any constriction (FIGS. 8, 10). Intracellular hyphae (4-7 $\mu \mathrm{m}$ diam) build few coils mainly at the outermost cortical cells, formed only by 1-2 loops (FIG. 11). The hyphae profusely invade the cells of the middle cortical parenchyma and produce abundant intracellular vesicles in bundles, some coils and relatively sparse arbuscules (FIGs. 15-16). Arbuscules are abundant in early stages of plant development and rare at this stage, never occurring together with vesicles within the same cell. Single vesicles, or bundles of 2-6 vesicles, are borne from a central hypha (up to $5 \mu \mathrm{m}$ ) within the plant cell (FIG. 14). Within the same root, vesicles at different stages of development are found. The youngest are small (10-30 $\mu \mathrm{m}$ diam) and have a dense cytoplasm (FIG. 12). A wide interface (1.5-3 $\mu \mathrm{m}$ ) 

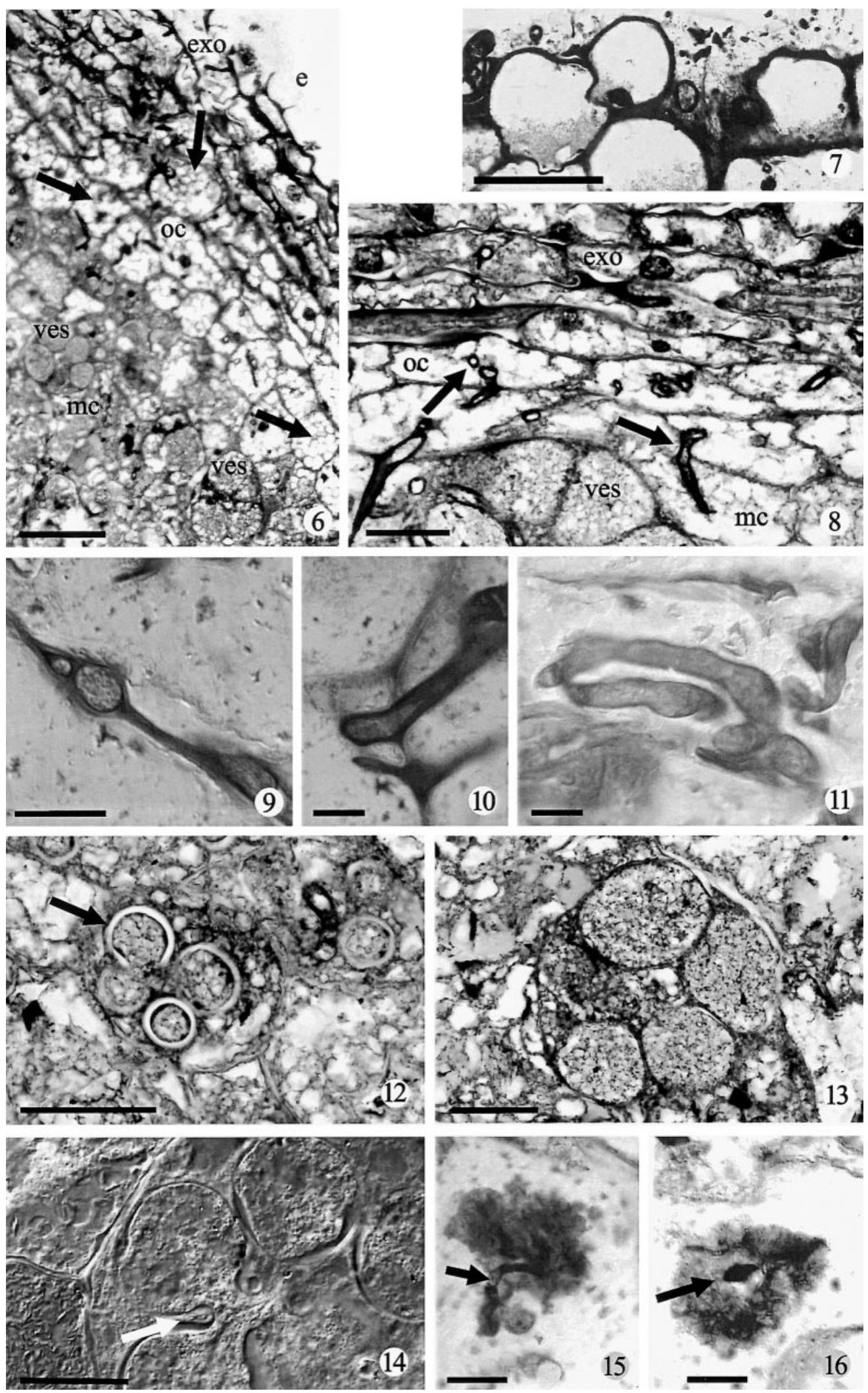

pg $1144 \quad \# 4$

FIGS. 6-16. Differential interface contrast (14) and light micrographs of Arachnitis uniflora roots at stage (i). 6. Cross section of a young turgent root. Note the abundant starch grains in the outer cortex (arrows) and vesicles in the middle cortex. 7. Irregular epidermis surface and crypts filled with debris. 8. Cross section of the outermost root layers. In the exodermis and outer cortical layers intercellular hyphae can be seen (arrows). Tangential elongated outer cortical cells show 
filled by a homogenous content is apparent between the fungal wall $(0.3 \mu \mathrm{m})$ and the plant plasma membrane. Vesicle cytoplasm turns more homogenous when vesicles reach 25-40 $\mu \mathrm{m}$ (FIG. 13). Older vesicles $(<65 \mu \mathrm{m}$ diam each) grow to occupy the whole cell, which also becomes enlarged, with vacuolated cytoplasm that appears like a net (FIGs. 6, 8). Almost no plant cytoplasm is left, and the nucleus is pressed between vesicles or between the vesicles and the cell wall. In longitudinal sections, older vesicles are found far from the root apex. The innermost cortical layers of isodiametric cells $(30 \mu \mathrm{m}$ diam $)$ have abundant starch grains and many intercellular spaces (FIG. 22). Very few hyphae $(1.5-5 \mu \mathrm{m}$ diam) grow into these cells. The root apex is never colonized, with the fungal infection spreading along the root length as seen in longitudinal sections. The pattern of root colonization is similar to the Paris-type, having fewer coils and vesicles in bundles.

When shoot and flower bud are up to $1.5 \mathrm{~cm}$, roots are elongated and turgent (stage ii). The cells of the exodermis and the outer cortical layers no longer have intracellular content, and the longitudinally elongated cells change their shape by turning more isodiametric $(16-30 \times 14-25 \mu \mathrm{m})$ (FIG. 18). The external periclinal wall of the epidermal cells becomes thicker, and the protruding epidermal cells show the anticlinal walls also thickened $(2 \mu \mathrm{m})$. Large quantities of bacteria invade not only the epidermal depressions but also the interior of the plant cells, especially the intercellular spaces within the internal cortical layer (FIG. 21). New hyphal penetrations cannot be seen. In the infected middle cortical layers, the boundaries between the hyphae, vesicles and plant cells become blurred (FIG. 19), turning into a wavy shapeless structure, with some remaining hyphae and scarce thick-walled vesicles (FIG. 20). This amorphous structure apparently comprises mainly collapsed plant cells and vesicles. Cells that were not colonized remain intact (50-75 $\mu \mathrm{m}$ diam) (FIG. 17). Arbuscule remnants sometimes are seen as thin branches $(1 \mu \mathrm{m})$ surrounded by fine, bluish granules. The innermost hyphal coils and vesicles of the middle cortex layers degrade earlier than those closer to the exodermis. All starch grains disappear and the inner cortex region, in which cells were very sparsely colonized before, loses its fungal content.

When shoot and flower have withered, roots are elongated and wrinkled. (stage iii). Epidermis, exodermis as well as outer cortical parenchymatic root layers persist in being longer than the rest of the root tissues. The hyphae within those tissues maintain their structure but no longer have cytoplasm content, and their walls stain dark purple with Cresyl blue. Disorganization of plant cell cytoplasm and loss of cell structural integrity begins at the middle and in the inner cortical parenchyma as well as in the central vascular cylinder, delayed toward the outer layers. A large development of loosely arranged mycelium remains within the degenerated middle and inner parenchymatic cortical layer and conductive tissue. Finally, the innermost parenchymatic cortical layers and the vascular tissues are digested, except for a small group of thick-walled xylema elements. At this point hyphae, which probably belong to saprophytic species of Ascomycota or Basidiomycota (isodiametric, $2 \mu \mathrm{m}$ diam, regularly septated and unclumped) are present.

\section{DISCUSSION}

The fungi associated with A. uniflora have features characteristic of AM fungi (e.g., hyphae, vesicles, arbuscules and coils). Molecular analysis performed by Bidartondo et al (2002) confirmed this association and identified the endophyte as a Glomus Group A species, not only for A. uniflora but also for other myco-heterotrophic plants such as Voyriella parviflora and five species of Voyria. A novel aspect of the relationship among AM fungi and their nonphotosynthetic partners, revealed by DNA analysis, is that both partners are highly selective in their choice of symbiont (Bidartondo et al 2002). The same Glomus lineage was found forming mycorrhizae in three adjacent photosynthetic plants belonging to three families, Apiaceae, Cupressaceae and Nothofagaceae, strongly suggesting their interconnection (Bidartondo et al 2002). It would be of great interest to determine the partner plants in other ecosystems (Chile,

$\leftarrow$

abundant starch grains. Note old vesicles with vacuolized cytoplasm. 9. Hyphae between cells. 10. Intracellular spreading hyphae in outer cortex. 11. Coil. 12-14. Vesicles in bundles at different stages of development: 12. Young vesicles, note the wide interface around them (arrow). 13. Older vesicles occupying almost the whole root cell. Note the dense cytoplasm. 14. Vesicles bundle born from a main hypha at the center of the root cell (arrow). 15, 16. Degraded arbuscules of which only the main hypha at the center remains (arrow). (e) epidermis, (exo) exodermis, (mc) middle cortex, (oc) outer cortex, (ves) vesicles. Scale bars: $6,8,12-16=50 \mu \mathrm{m} ; 7=25 \mu \mathrm{m} ; 9-11=10 \mu \mathrm{m}$. 

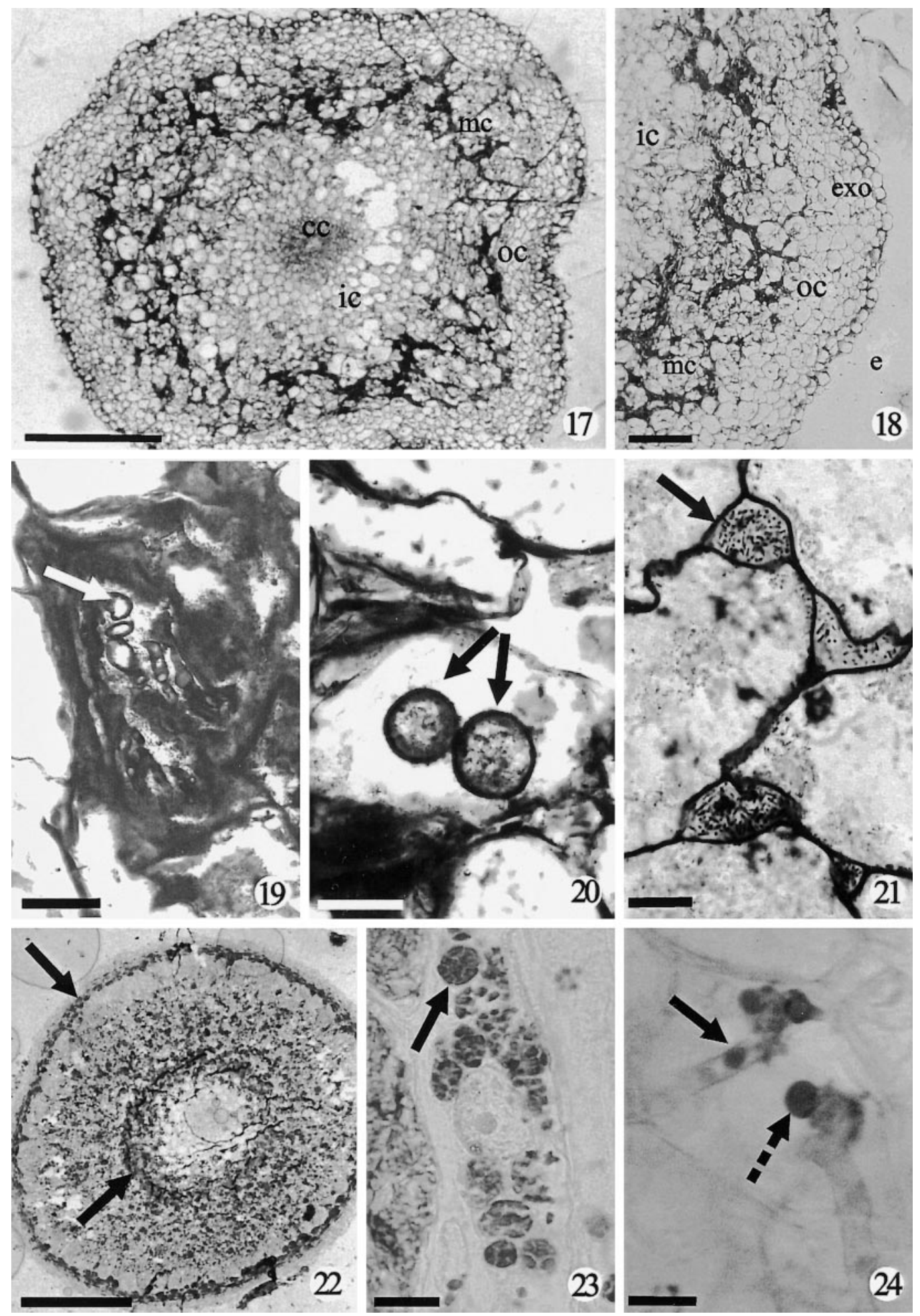

Figs. 17-24. Mycorrhizal structures in the roots of Arachnitis uniflora at stage (ii) and (iii). 17. Cross section of the root with central cylinder, cortex differentiated in inner-, middle- and outer-cortex layers. Note the collapsed tissue of the middle cortex. Outer cortex not easily discerned from exodermis and epidermis. 18. Root transection showing the more isodiametric shape of the epidermis, exodermis and outer cortical cells. 19. Detail of the degenerated midcortical tissue; some intact hyphae remain within it (arrow). 20. Sectioned vesicles showing thickened walls. 21. Cross section of the inner cortical layer showing intercellular spaces with bacteria. 22. Root cross section stained with Lugol. Note the more abundant starch accumulations in the outer and inner cortical layers (arrows). 23. Outer cortical cell containing large amounts of composed 
Falkland Islands and Bolivia) where Arachnitis also occurs and its associated plants might be different.

A. uniflora revealed a remarkably distinct pattern of AM colonization. Some features of this mycorrhizal symbiosis are unique and were not seen in other myco-heterotrophic plants that supposedly are associated with AM fungi (Schmid and Oberwinkler 1993, Imhof 1997, Imhof and Weber 1997, Imhof 1998, 1999a, b, c, Yamato 2001).

Infection and colonization.-No roughened patches such as in Thismia rodwayi (Campbell 1968) were seen in A. uniflora. Here the hyphae contact the roots, adhere to it and penetrate without forming appresoria. Penetration of plant cell walls is not associated with a narrowing of the hyphal diameter, as it is in most other cases (Smith and Read 1997).

A. uniflora colonization is initiated through epidermal cells in an intercellular way as seen partly in V. truncata (Imhof and Weber 1997), while others species have only intracellular colonization (Sciaphila tosaensis, Yamato 2001, Voyria tenella, Imhof 1997, Voyria aphylla, Imhof 1999a).

Arbuscules.-Arbuscules are abundant in A. uniflora at the beginning of the establishment of the association, when the seedling starts to develop (0.8$5 \mathrm{~mm}$ ). Later, when the plant is almost ready to flower, they are scarce (stage i), remaining only as a partially digested structure. Imhof (1999c, 2001) recorded some arbuscules in fully mature plants, while other authors (Terashita and Kawakami 1991, Schmid and Oberwinkler 1993, Imhof 1997, Weber and Imhof 1997, Imhof 1998, 1999b) did not see them at all in the plants stages they studied. It is possible that they were absent because the plants were studied at the flowering stage, which is when the stored plant resources already have been consumed. We presume that arbuscules might be formed mainly during the maximum nutrient exchange, when the plants accumulate storage substances for the forthcoming flowers and fruit. It would be of interest to determine if this is related to the condition of being a perennial plant that flowers every year or of being hapaxanthic (production of flowers only once in the life of the plant).

Vesicles.-In A. uniflora other unique structures are the intracellular vesicles. They are generally in large numbers within one plant cell and arranged in bun- dles. At first the young vesicles are small and surrounded by a wide interface which might be engaged in an active exchange of nutrients. The enlargement of vesicles and host cells is notable and is the first record of this kind of vesicle arrangement. An alternative hypothesis is that these structures are swollen hyphae. However, if this is the case, they are entirely different from what Imhof (1997) observed.

Few vesicles turn into spores in the final developmental stages of the symbiosis and are always intracellular. Inter and intracellular spores were observed in Burmannia linkiwensis (Terashita and Kawakami 1991).

Coils.- Hyphal coils, having few loops, which are similar to those found in photosynthetic plants associated with AM fungi, were seen in Arachnitis as well as in Burmannia tenella, (Imhof 1999c) and Voyria truncata (Imhof and Weber 1997). Instead, orchidoid-like pelotons commonly were seen in other myco-heterotrophic plants such as in Triuridaceae, (Imhof 1998, Yamato 2001) Burmanniaceae (McLennan 1958, Terashita and Kawakami 1991, Imhof 1999b) and Lycopodiaceae (Schmid and Oberwinkler 1993), even though in these taxa they might be formed by AM fungi.

Lysis. - The collapse and degeneration of some fungal structures is a consistent feature of arbuscular and orchid types of association, but its significance is uncertain (Smith and Smith 1990). Degeneration also was reported for almost all myco-heterotrophic plants such as Voyria tenella (Imhof 1997), V. truncata (Imhof and Weber 1997), Burmannia tenella (Imhof 1998), Sciaphyla tosaensis (Yamato 2001), Psilotum and Lycopodium (Schmid and Oberwinkler 1993) and others. In Arachnitis, degeneration does not occur evenly, with the hyphae retaining their shape in the exodermis, outer and inner root cortex, while in the middle cortex they break down. A similar pattern is seen in V. truncata (Imhof and Weber 1997) and Afrothismia winkleri (Imhof 1999b). The colonization regions degenerate into amorphous fungal material, as occurs in Sciaphila tosaensis (Yamato 2001) and almost any other myco-heterotrophic plant, but here cell boundaries still can be discerned while in Arachnitis root cells hardly maintain their shape.

Germination and infection in nature have not been observed. It is likely that the minute seeds of

\section{$\leftarrow$}

starch rosettes (arrow). 24. Oil drops within hyphae (simple arrow) and outside it (dashed arrow). (e) epidermis, (cc) central cilinder, (exo) exodermis, (mc) middle cortex, (oc) outer cortex, (ves) vesicles. Scale bars: 17-18, $22=1 \mathrm{~cm}$; $19=20 \mu \mathrm{m}$; 20-21, 23-24 = $10 \mu \mathrm{m}$. 
A. uniflora sit in the soil for some time, eventually reaching the deepest levels of the organic soil, helped by rain or melted snow and the accumulation of new organic material. It is still unclear when the fungal infection takes place, but it must be very early in plant development because small seedlings (ca 1 $\mathrm{mm}$ diam) already show many arbuscules. In this association the plant cheats the fungus, which forms abundant arbuscules that might bring carbon to the myco-heterotrophic plant, while in autothrophic plants arbuscules are involved in the uptake of carbon by fungi. The growing plants begin to accumulate abundant starch grains within root cells. The root system gets bigger, and the shoot bud begins to grow. All starch might be consumed to produce the shoot, the single flower and fruit structures. After producing fruit, the root system and the fungal hyphae degenerate, and the plant dies. It seems possible that Arachnitis thrive invisibly underground for an unknown time and then end their lifecycle with flowering (perennial and monocarpic) or complete the lifecycle within one season (annual).

It is possible that all of the carbon of the underground parts of Arachnitis is used in growing the stem and flowering. After fruiting and during plant degeneration, the rest of the tissues could be used up by decomposing organisms. Because saprophytic capacity has not been determined in higher plants so far, a net carbon flow may be inferred for the achlorophyllous species. Considering the plasticity and the opportunistic behavior of fungi, AM might behave as saprophytic as some ectomycorrhizal fungi do (Bending and Read 1997, Kohzu et al 1999), although this should be confirmed.

It will be of particular interest to study the physiology of the association and C transfer from chlorophyllous to achlorophyllous plant through mycorrhizal hyphae using ${ }^{14} \mathrm{C}$ tracer.

\section{ACKNOWLEDGMENTS}

We would like to thank C. Urcelay, A.A. Cocucci and E. Nohura for their comments on the manuscript and their suggestions, P.D. Hobson for the final manuscript proofreading, as well as the support of CONICET of which A.S. is a member.

\section{LITERATURE CITED}

Bidartondo M, Redecker D, Hijri I, Wiemken A, Bruns T, Domínguez L, Sérsic A, Leake J, Read D. 2002. Epiparasitic plants specialized on arbuscular mycorrhizal fungi. Nature 419:389-392.

Bending GD, Read DJ. 1997. Lignin and soluble phenolic degradation by ectomycorrhizal and ericoid fungi. Mycol Res 101:1348-1354.
Campbell EO. 1968. An investigation of Thismia rodwayi $\mathrm{F}$. Muell. and its associated fungus. Trans Roy Soc New Zealand Bot 3:209-219.

Cribb PJ, Wilkin P, Clements M. 1995. Corsiaceae: a new family for the Falkland Islands. Kew Bull 50:171-172.

Dimitri MJ. 1972. Una nueva especie del género "Arachnitis" Phil. (Corsiaceae). Revista Fac Agron Univ Nac La Plata 48:37-45.

Domínguez LS, Sérsic A. 2001. First record of VAM in the myco-heterotrophic Arachnitis uniflora (Corsiaceae): morphological development of the association. ICOM 3. 3rd International Conference on Mycorrhiza. Adelaide, Australia. p C4 05.

Dressler RL. 1993. Phylogeny and classification of the Orchid Family. Portland, Oregon: Dioscorides Press. $314 \mathrm{p}$.

Gerlach D. 1984. Botanische Mikrotechnik. Eine einführung, Stuttgart. G. Thieme. 311 p.

Ibisch PL, Neinhuis C, Rojas PN. 1996. On the biology, biogeography, and taxonomy of Arachnitis Phil. nom. cons. (Corsiaceae) in respect to a new record from Bolivia. Willdenowia 26:321-332.

Imhof S. 1997. Root anatomy a mycotrophy of the achlorophyllous Voyria tenella Hook. (Gentianaceae). Bot Acta 110:298-305.

- 1998. Subterranean structures and mycotrophy of the achlorophyllous Triuris hyalina (Triuridaceae). Can J Bot 76:2011-2019.

- 1999a. Root morphology and anatomy and mycotrophy of the achlorophyllous Voyria aphylla (Jacq.) Pers. (Gentianaceae). Mycorrhiza 9:33-39.

1999b. Anatomy and mycotrophy of the achlorollyllous Afrothismia winkleri. New Phytol 144:533-540.

- 1999c. Subterranean structures and mycorrhiza of the achlorophyllous Burmannia tenella (Burmanniaceae). Can J Bot 77:637-643.

. 2001. Subterranean structures and mycotrophy of the achlorophyllous Dictyostega orobanchoides (Hook.) Miers (Burmanniaceae). Rev. Biol. Trop. 49:237-245. , Weber HC. 1997. Root anatomy and mycotrophy (AM) of the achlorophyllous Voyria truncata (Standley) Standley \& Steyemark (Gentianaceae). Beitr Biol Pflanz 68:113-123.

Kohzu A, Yoshioka Taando T, Takahashi M, Koba K, Wada E. 1999. Natural ${ }^{13} \mathrm{C}$ and ${ }^{15} \mathrm{~N}$ abundance of field-collected fungi and their ecological implication. New Phytol 144:323-330.

Largent D, Johnson D, Watling R. 1977. How to identify mushrooms to genus III: microscopic features. California: Mad River Press Inc. 148 p.

Leake JR. 1994. The biology of myco-heterotrophic ("saprophytic") plants. New Phytol 127:171-216.

Maas PJ, Snelders H, Benthem J, Ruyters, van der Mass K. 1986. Burmanniaceae. Flora Neotropica. New York: $42 \mathrm{p}$.

Mabberly DJ. 1987. The plant book. Cambridge: Cambridge University Press. 706 p.

McLennan EI. 1958. Thismia rodwayi $\mathrm{F}$. Muell. and its endophyte. Austral J Bot 6:25-37. 
Neyland R, M Hennigan. 2003. A phylogenetic analysis of large-subunit (26S) ribosome DNA sequences suggests that the Corsiaceae are polyphiletic. N Zeal Jour Bot 41:1-11.

O'Brien TP, McCully ME 1981. The study of plant structure. Principles and selected methods. Oxford: Blackwell Scientific Publications. R45 p.

van der Pijl L. 1934. Die Mykorrhiza von Burmannia und Epirrhizanthes und die Fortflanzung ihres Endophyten. Recueil Trav Bot Néerl 31:761-779.

Robinson D, Fitter A. 1999. The magnitude and control of Carbon transfer between plants linked by a common mycorrhizal network. J Exp Bot 50:9-19.

Rübsamen, T. 1986. Mofologische, embryologische und systematische Untersuchungen an Burmanniaceae und Corsiaceae (mit Ausblick auf die Orchidaceae-Apostasiosideae). Diss Bot 92. J. Cramer, Berlin. 310 p., 98 figures.

Schmid E, Oberwinkler E. 1993. Mycorrhizae like interaction between the achlorophyllous gametophyte of $L y$ - copodium clavatum and its fungal endophyte studied by light and electron microscopy. New Phytol 124:69-81.

Smith SE, Smith FA. 1990. Structure and function of the interfaces in biotrophic symbioses as they relate to nutrient transfer. New Phytol 114:1-38.

Smith SE, Read DJ. 1997. Mycorrhizal symbiosis. San Diego: Academic Press. 605 p.

Taylor DL, Bruns TD, Leake JR, Read DJ. 2002. Mycorrhizal specificity and function in myco-heterotrophic plants. In: van der Heijden MGA, Sanders I, eds. Mycorrhizal ecology. Ecological studies. Vol. 157. p 375-413.

Terashita T, Kawakami Y. 1991. An endomycorrhizal fungus of Burmannia liuliuensis. Trans Mycol Soc Japan 32: 207-215.

Yamato M. 2001. Identification of a mycorrhizal fungus in the roots of achlorophyllous Sciaphila tosaensis Makino (Triuridaceae). Mycorrhiza 11:83-88.

Zhang D, Saunders RMK. 1999. Corsiopsis chinensis gen. et sp. nov. (Corsiaceae): first record of the family in Asia. Systematic Botany 24:311-314. 